\title{
Parametric identification of the mathematical model of the functioning of tribosystems in the conditions of boundary lubrication
}

\author{
A.V. Voitov \\ Kharkiv Petro Vasylenko National Technical University of Agriculture, Kharkiv, Ukraine \\ *E-mail: K1kavoitov@gmail.com
}

Received: 7 April 2021: Revised: 24 June: Accept: 10 August 2021

\begin{abstract}
The parametric identification of the tribosystem as an object of modeling the functioning of tribosystems in the conditions of boundary lubrication is performed in the work. Using the analysis of the dimensions of significant factors, expressions are obtained to calculate the gain and time constants.

It is established that the coefficient $K_{1}$ takes into account the degree of influence of the load, sliding speed, tribological characteristics of the lubricating medium on the quality factor of the tribosystem. It is shown that the increase in the coefficient $K_{1}$ will have a positive effect on the processes inherent in tribosystems during operation. Coefficient $K_{2}$ - characterizes the magnitude of the change in volumetric wear rate and friction coefficient when changing the magnitude of the load, sliding speed, quality factor of the tribosystem. Coefficient $K_{3}$ - characterizes the ability of the tribosystem to self-organize when changing the values of the input parameters by rearranging the surface layers of materials from which the triboelements are made during secondary running-in. It is shown that the value of the coefficient is large $K_{3}$ will contribute to the rapid change in the roughness of the friction surfaces, the restructuring of the structure of the surface layers, the appearance of oxidizing films on the friction surfaces (secondary structures).

It is proved that the time constant $T_{1}$ - this is the time required to change the roughness of the friction surfaces and rearrange the structure of the materials of the surface layers when changing external conditions. Time constant $T_{2}$ characterizes the time during which there is a stabilization of the temperature gradient by volume of triboelements, taking into account the thermal conductivity of materials when changing external conditions. Time constant $T_{3}$ characterizes the time during which the tribosystem returns to a steady state of operation after the cessation of the outrageous force, or the time to stabilize the parameters in the new mode of operation. It is proved that the value $T_{3}$ will be optimal for the process of self-organization. It is shown that one of the factors that can control the value $T_{3}$, this is the sliding speed $v_{s l}$.

Keywords: tribosystem; mathematical model; differential equations; parametric identification; coefficient of gain; time constant; boundary lubrication; quality factor of the tribosystem; dissipation speed

\section{Introduction}

Analysis of the current state of mathematical models of friction and wear, as well as methods for calculating wear and predicting the resource, shows the increasing attention of researchers to this problem. This is due to high material costs in the design, testing and refinement of new models of equipment before they are put into production. One of the ways to reduce material costs is to replace laboratory and bench tests with mathematical modeling and resource prediction at the design stage.
\end{abstract}


For the development of mathematical models, both analytical and numerical methods are used. In this case, the task is posed that mathematical models should be multifactorial and take into account the processes of deformation and destruction of the surface layers of tribosystems, the formation of wear-resistant structures on friction surfaces and the exchange of friction surfaces with matter and energy. Such multi-level and multifactorial tasks are solved by various methods and different approaches, while they have one goal - resource forecasting.

This work is a continuation of work [1], where a third-order differential equation is obtained for modeling the boundaries of stable operation of tribosystems under boundary lubrication conditions. To use this approach, it is necessary to obtain expressions for calculating all the coefficients and time constants that are included in the left and right sides of the equation. The presence of such coefficients will make it possible to simulate the processes of friction and wear in tribosystems.

\section{Literature review}

The authors of the work [2] studies on modeling the processes of friction and wear at the mesoscale level. As a methodological approach, the authors use the finite element method, where surface roughness is represented by the combined law of friction. In the developed model, the relations of wear of the friction surfaces and the corresponding mechanisms of energy dissipation on the spots of actual contact are considered. According to the authors, such a methodological approach makes it possible to simulate the wear process with sufficient accuracy. A similar approach is used by the authors of the work [3]. The concepts developed in this article are based on statistical analysis, which is based on the mechanisms of energy dissipation during friction of contacting sliding surfaces.

In work [4] it is shown that the dynamics of the tribosystem is well reproduced by simplified models obtained using the Markov process, even in the presence of several minima of the investigated functions. After evaluating the parameters of the tribosystem by numerical simulation, the authors calculate the average wear rate and friction losses when external forces and temperature change.

In work [5] the physical mechanisms of formation and transformation of corpuscular-vortex perturbations in the contact of the tribosystem, which are based on the quantum-mechanical exchange mechanism of interaction, are considered. The presence of a contact gap determines the generation of pairs of quasiparticles-perturbations, stabilized by wavelength and frequency. It is established in the work that the internal instability and collapse processes in such a system of perturbations lead to defect formation in the material of the tribosystem and underlie the emergency modes of friction.

In the works $[6,7]$ performed analysis of the strength and durability of the surface layer material by friction. The authors propose to take into account the presence of two areas of accumulation of damage and the type of mechanism of destruction: the area of multicycle fatigue and a layer of debris. Methods for estimating the parameters of the durability model for the region of multicycle fatigue are proposed. The connection between the stress-strain state and the fatigue strength characteristics of the material with the characteristics of the material fracture model is obtained. The analysis of the received relations showed that any physical action on a surface, leads to decrease in structural inhomogeneity and prevents development of cracks, promotes increase of wear resistance.

In work [8] the analysis of various methods for calculating wear and predicting the resource is given and it is concluded that analytical methods do not allow taking into account the dynamics of changing the operating modes of the contact, and numerical methods seem to be promising. The author of the work proposed to describe wear by an array of probability vectors of wear values of discrete points of the surface, which are modeled by non-stationary random functions of the Markov type, and wear is estimated by the mathematical expectation of the probability of finding surface elements in a certain state.

In work [9] theoretical studies on the substantiation of the methodology for modeling stationary processes of friction and wear in tribosystems under conditions of boundary lubrication are presented. The authors have developed a technique for modeling the characteristics of the actual contact patch and a mathematical model of the rate of dissipation in the tribosystem, which allow modeling the rate of volumetric wear and the coefficient of friction in stationary modes.

The analysis of the above works shows the versatility in the approaches to the construction of mathematical models of the processes of friction and wear in tribosystems. In our opinion, the most promising are numerical methods based on differential equations, which make it possible to simulate the dynamics of the transient process. Obtaining such models is associated with the stages of structural and parametric identification. Structural identification of the tribosystem is carried out in the work [1], where the third-order differential equation is obtained. The obtained equation can be used provided that all the parameters that are included in the left and right sides of the equation are determined. Obtaining such expressions is called parametric identification of a mathematical model. 


\section{Purpose}

The purpose of this work is to perform parametric identification of the tribosystem and obtain expressions for the gains and time constants, which are included in the differential equation for modeling the processes of friction and wear in tribosystems.

\section{Methods}

To substantiate the methodological approach in research, we use the equation of the dynamics of the functioning of the tribosystem, which is given in [1]. The third-order differential equation is written in operator form:

$$
\begin{aligned}
& \left(T_{1} T_{2} T_{3}\right) p^{3}+\left(T_{1} T_{2}+T_{1} T_{3}+T_{2} T_{3}\right) p^{2}+\left(T_{1}+T_{2}+T_{3}+K_{2} K_{3} T_{1}\right) p+ \\
& +K_{2} K_{3}+1=\left(K_{1} K_{2} T_{3}\right) p+K_{1} K_{2} .
\end{aligned}
$$

$p$ - a differentiation operator that is equivalent to a record $d / d t$;

$T_{1}, T_{2}, T_{3}$ - time constants, dimension s;

$K_{1}, K_{2}, K_{3}$ - coefficients of gain, dimensionless quantities.

The right part of the differential equation (1) contains the first derivative of the input signal, which is represented as the product of the coefficients $K_{1} K_{2}$ and time constant $T_{3}$. The dynamics of the tribosystem is influenced not only by the magnitude of the values $K_{1}, K_{2}, T_{3}$, as well as the rate of change over time (the first derivative).

The left side of the equation is the reaction of the tribosystem to the input signal. Time constants of the tribosystem $T_{1}, T_{2}, T_{3}$ have the dimension of time and characterize the inertia of the processes occurring in the tribosystem, during running-in, or during changes in operating modes.

The purpose of parametric identification is to determine the expressions for the calculation of the above coefficients and time constants, so that when substituting them in equation (1), the right and left parts differ the least.

When solving the problems of friction and wear, a methodical approach to the theory of similarity and modeling is often used, where dimensional analysis methods are used to obtain dimensionless criteria. Analyzing the dimensional factors that affect the process, but do not depend on each other, you can get dimensionless criteria (coefficients) that adequately describe the process in similar (different in size and design) physical objects.

The procedure of parametric identification or finding expressions for calculation $K_{1}-K_{3}, T_{1}-T_{3}$, which characterize the dynamics of the functioning of tribosystems, there is an experimental material that allows you to choose the most significant factors.

Such factors include.

1. The diameter of the actual contact spot $d_{a c s}, \mathrm{~m}$, the number of contact spots on the friction surface $n_{a c s}$, $\mathrm{pc}$, and stress on the actual contact spots $\sigma_{a c s}, \mathrm{~Pa}$. Depends on the load on the tribosystem $N, \mathrm{~N}$, modulus of elasticity and roughness of contact materials of triboelements. Calculated according to the formulas given in the work [9].

2. Deformation rate in movable $\dot{\varepsilon}_{m o v}$ and fixed $\dot{\varepsilon}_{f i x}$, triboelements, $\mathrm{s}^{-1}$. Depends on the load $N, \mathrm{~N}$, sliding speed $v_{s l}, \mathrm{~m} / \mathrm{s}$, modulus of elasticity and Poisson's ratio of contact materials of triboelements. Calculated according to the formulas given in the work [9].

3. Tribosystem shape factor $K_{\phi}, \mathrm{m}^{-1}$, takes into account the areas of friction and the volumes located under the areas of friction in the movable and fixed triboelements. Calculated by the formula [10].

4. Coefficient of thermal conductivity $a, \mathrm{~m}^{2} / \mathrm{s}$, takes into account the thermal conductivity of movable materials $a_{m o v}$ and fixed $a_{f i x}$ triboelements. Reference value.

5. Tribological properties of the lubricating medium $E_{u}, \mathrm{~J} / \mathrm{m}^{3}$, are determined on a four-ball friction machine and take into account the anti-wear and anti-emergency properties of lubricants, calculated by the formula [11].

6. Rheological properties of the structure of movable materials $\delta_{m o v}$ and fixed $\delta_{f i x}$ triboelements, dimension $\mathrm{dB} / \mathrm{m}$. Takes into account the internal friction of the material structure. The values of internal friction for steels, cast irons, bronzes are presented in the paper [12].

7. Smaller area of friction of one of the triboelements, $F_{\min }, \mathrm{m}^{2}$. 
8. Volumes of material which are located under the areas of friction at the movable $V_{m o v}, \mathrm{~m}^{3}$ and fixed $V_{f i x}, \mathrm{~m}^{3}$ triboelements.

9. The volume of movable material $V_{d m o v}$ and fixed $V_{d f i x}$ triboelements, $\mathrm{m}^{3}$, involved in the deformation during friction, is calculated by formulas:

$$
\begin{aligned}
& V_{d m o v}=F_{\text {max }} \cdot h_{d m o v}, \mathrm{~m}^{3}, \\
& V_{d f i x}=F_{\text {min }} \cdot h_{d f i x}, \mathrm{~m}^{3},
\end{aligned}
$$

where $F_{\max }$ - large area of friction of one of the triboelements;

$h_{d m o v}$ and $h_{d f i x}$ - depth of propagation of deformation in movable and fixed triboelements, $\mathrm{m}$.

In work [13] the proposed physical quantity is the quality factor of the tribosystem $Q$, and the dependences of the change in the quality factor on the initial value are given $Q_{0}$ to the maximum value $Q_{\max }$, which increases during running-in.

\section{Results}

Coefficient of gain $K_{1}$, included in the differential equations and their solutions, in the theory of identification of dynamic objects is called the coefficient that takes into account the degree of influence of the input signal (load, sliding speed, tribological characteristics of the lubricating medium), the magnitude of the output signal (quality of the tribosystem). Based on this physical concept and using the methods of dimensionality of similarity theory and modeling, we obtain the expression:

$$
K_{1}=\frac{Q_{\max }}{Q_{0}}
$$

where $Q_{0}$ and $Q_{\max }$ - the initial value of the quality factor of the tribosystem and the value of the quality factor formed during the running-in of the tribosystem. Determined by the formulas given in the work [13].

As follows from expression (4), the ratio of the maximum value of the quality factor, which is characteristic of the tribosystem after completion of running-in, to the quality factor of the tribosystem $Q_{0}$ before starting, evaluates the possibility of the tribosystem to change the structure of the surface layers of the materials of the triboelements under load. The increase in the quality factor of the tribosystem is based on the concept of compatibility of materials in the tribosystem. Increasing the ratio $K_{1}$ will have a positive effect on the processes inherent in tribosystems during operation.

Coefficient $K_{2}$ - characterizes the magnitude of the change of the output parameters (volumetric wear rate and friction coefficient) when changing the values of the input parameters (load, slip speed, quality factor of the tribosystem).

Based on the analysis of dimensions, we write an expression to determine the coefficient $K_{2}$ :

$$
K_{2}=\frac{W_{F R} \cdot K_{f}}{Q_{\max } \cdot a_{g}},
$$

where $W_{F R}$ - the rate of dissipation in the tribosystem, $\mathrm{J} / \mathrm{s}$, is calculated by the formulas given in the work [9];

$a_{g}$ - the coefficient of thermal conductivity of materials of movable $a_{m o v}$ and fixed $a_{f i x}$ triboelements, dimension $\mathrm{m}^{2} / \mathrm{s}$, calculated by expression:

$$
a_{g}=\frac{2 \cdot a_{m o v} \cdot a_{f i x}}{a_{m o v}+a_{f i x}}, \mathrm{~m}^{2} / \mathrm{s} .
$$

The physical meaning of the coefficient $K_{2}$ - this is the sensitivity of the tribosystem to changes in external influences (load, slip speed, quality factor of the tribosystem). Great value of the coefficient $K_{2}$ will promote the appearance of fluctuations in wear rate and friction coefficient during the operation of the 
tribosystem, especially in transient modes. Conversely, small value $K_{2}$ will positively affect the operation of the tribosystem.

From the analysis of formula (5) it is possible to develop recommendations for reducing the value of the coefficient $K_{2}$. To do this, increase the maximum value of the quality factor of the tribosystem and the value of the coefficients of thermal conductivity of movable materials $a_{m o v}$ and fixed $a_{f i x}$ triboelements.

Coefficient $K_{3}$ - characterizes the ability of the tribosystem to self-organize when changing the values of the input parameters (load, slip speed, quality factor of the tribosystem).

Based on the analysis of dimensions, we write an expression to determine the coefficient $K_{3}$ :

$$
K_{3}=\frac{R S_{T S(\max )}^{2} \cdot a_{g}}{\dot{\varepsilon}_{g}},
$$

where $R S_{T S(\max )}$ - maximum value of rheological properties of connected materials in the tribosystem after completion of running-in, dimension $\mathrm{m}^{-1}$, is calculated by the formulas given in the work [12];

$\dot{\varepsilon}_{g}$ - the value of the rate of deformation of the surface layers of the materials of movable and fixed triboelements, the dimension $\mathrm{s}^{-1}$, is calculated by the formulas given in the work [9].

$$
\dot{\varepsilon}_{g}=\frac{2 \cdot \dot{\varepsilon}_{m o v} \cdot \dot{\varepsilon}_{f t x}}{\dot{\varepsilon}_{m o v}+\dot{\varepsilon}_{f t x}}, 1 / \mathrm{s} .
$$

Deformation rates in the surface layers of the movable $\dot{\varepsilon}_{\text {mov }}$ and fixed $\dot{\varepsilon}_{f i x}$ triboelements are determined by the expressions given in the work [9]:

$$
\begin{gathered}
\dot{\varepsilon}_{\text {mov }}=75\left(1+\mu_{\text {mov }}\right)\left(0,86-1,05 \mu_{\text {mov }}\right) \frac{\sigma_{a c s} \cdot v_{s l}}{E_{m o v} \cdot d_{a c s}}, 1 / \mathrm{s} ; \\
\dot{\varepsilon}_{f i x}=75\left(1+\mu_{f i x}\right)\left(0,86-1,05 \mu_{f i x}\right) \frac{\sigma_{a c s} \cdot v_{s l}}{E_{f i x} \cdot d_{a c s}}, 1 / \mathrm{s},
\end{gathered}
$$

where $\mu_{m o v}$ and $\mu_{f i x}$ - Poisson's ratios of materials of movable and fixed triboelements, reference value;

$v_{s l}$ - sliding speed, $\mathrm{m} / \mathrm{s}$;

$E_{m o v}$ and $E_{f i x}$ - modulus of elasticity of materials of movable and fixed triboelements, Pa.

The physical meaning of the coefficient $K_{3}$ - it is the ability of the tribosystem to return to the conditions of stable functioning after the cessation of action on the tribosystem of factors that outrage. According to the principle of Le Chatelier - Brown, any physical system that was in equilibrium is exposed to an outrageous factor, the equilibrium in the system is shifted so that the effect of this factor is weakened. Therefore, the inertial link $G_{3}$ in work [1] included in the scheme of the second block in the form of negative feedback and takes into account the ability of the tribosystem to weaken the perturbing force, by rearranging the surface layers of materials from which the triboelements are made during secondary running-in. Outrageous forces include load, sliding speed, tribological characteristics of the lubricating medium, quality factor of the tribosystem.

Great value of the coefficient $K_{3}$ will contribute to the rapid change in the roughness of the friction surfaces, the restructuring of the structure of the surface layers, the appearance of oxidizing films on the friction surfaces (secondary structures). It can be assumed that the coefficient $K_{3}$ characterizes the structural adaptability of materials in the tribosystem, or processes of self-organization during operation, especially in transient modes. Conversely, small value $K_{3}$ will negatively affect the work of the tribosystem, the ability to self-organize will be low.

From the analysis of formula (7) it is possible to develop recommendations for increasing the value of the coefficient $K_{3}$. This requires increasing the value of the rheological properties of the structure of the bonded

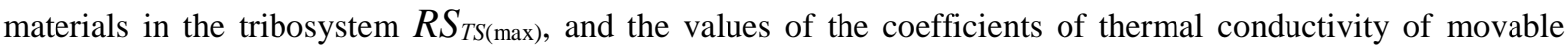
materials $a_{m o v}$ and fixed $a_{f i x}$ triboelements and reduce the values of the deformation rate of the surface layers of the materials of the movable and fixed triboelements. 
Time constant $T_{1}$, included in the differential equations of the dynamics of the tribosystem (1) characterizes the inertia of increasing the values of the quality factor of the tribosystem when changing external conditions (load, sliding speed, tribological properties of the lubricating medium).

The physical meaning of the time constant $T_{1}$ - this is the time required to change the roughness of the friction surfaces and rearrange the structure of the materials of the surface layers when changing external conditions, dimension - second.

Using the accumulated experience in running-in tribosystems, we write an expression for definition $T_{1}$ :

$$
T_{1}=\frac{t_{g}}{3}, \mathrm{~s},
$$

where $t_{g}$ - running-in time of the tribosystem, dimension - second.

Time constant $T_{2}$, which is included in the left part of the differential equation (1), characterizes the time during which there is a stabilization of the temperature gradient by volume of triboelements, taking into account the thermal conductivity of materials when changing external conditions, dimension - second.

Using the methods of dimensional analysis, we write an expression to determine $T_{2}$ :

$$
T_{2}=\frac{V_{g}}{a_{g} \cdot d_{a c s} \cdot n_{a c s}}, \mathrm{~s},
$$

where $V_{g}$ - the given volume of material of a tribosystem is defined by expression:

$$
V_{g}=\frac{2 \cdot V_{m o v} \cdot V_{f i x}}{V_{m o v}+V_{f i x}}, \mathrm{~m}^{3}
$$

where $V_{m o v}$ and $V_{f i x}$ - volumes of materials of movable and immovable triboelements, which are located under the working surfaces of friction, $\mathrm{m}^{3}$.

The diameter of the actual contact spot $d_{a c s}$ and the number of contact spots on the friction surface $n_{a c s}$ depends on the load $N$, the modulus of elasticity of the contacting materials and the roughness of the friction surfaces. It is calculated according to the formulas given in the work [9].

The physical meaning of the time constant $T_{2}$ - this is the time of temperature equalization generated on the spots of actual contact. Decrease in size $T_{2}$ will help reduce the time of temperature equalization. As follows from expression (12) for this it is necessary:

- to reduce the volume of triboelements, for example, to execute them thin-walled or to apply a covering or plates on friction surfaces;

- increase the thermal conductivity of triboelement materials.

Time constant $T_{3}$, which is included in both the right and left part of the differential equation (1), characterizes the time during which the return of the tribosystem to a stable mode of operation after the cessation of the outrageous force, or the time to stabilize the parameters in the new mode of operation. Performed by rearranging the surface layers when changing external conditions, dimension - second. This is the time during which there is a change in the roughness of the surface layers, the processes of deformation and hardening of the surface layers.

Using the methods of dimensional analysis, we write an expression to determine $T_{3}$ :

$$
T_{3}=\frac{V_{d g}}{\dot{\varepsilon}_{g} \cdot d_{a c s}^{3} \cdot n_{a c s}}, \mathrm{~s},
$$

where $V_{d g}$ - the volume of deformed surface layers is given, $\mathrm{m}^{3}$, is determined by the expression:

$$
V_{d g}=\frac{2 \cdot V_{d m o v} \cdot V_{d f i x}}{V_{d m o v}+V_{d f i x}}, \mathrm{~m}^{3}
$$


The volume of movable material $V_{d m o v}$ and fixed $V_{d f i x}$ triboelements, $\mathrm{m}^{3}$, involved in the deformation during friction, is calculated by formulas (2) and (3). The depth of strain propagation is determined by the expressions given in the paper [9]:

$$
h_{d m o v}=0,5 d_{a c s}\left(1-e^{-D_{m o v}}\right) \text {, }
$$

where

$$
\begin{gathered}
D_{n o v}=\frac{6,5 \cdot 10^{8} \cdot \sigma_{a c s}^{2}}{E_{m o v} \cdot E_{u}}, \\
h_{d f i x}=0,5 d_{a c s}\left(1-e^{-D_{f i x}}\right),
\end{gathered}
$$

where

$$
D_{f i x}=\frac{6,5 \cdot 10^{8} \cdot \sigma_{a c s}^{2}}{E_{f i x} \cdot E_{u}}
$$
quantities.

where $D_{m o v}$ and $D_{f i x}$ - coefficients of deformation in movable and fixed triboelements, dimensionless

Reducing the time constant $T_{3}$ helps to reduce the time of self-organization of the tribosystem. As follows from expression (11), to reduce $T_{3}$ the following measures must be taken.

1. Reducing the depth of deformation in the surface layers. As follows from formulas (16) - (19) the depth of deformation in the materials of triboelements is affected:

- the magnitude of the voltage at the spots of actual contact $\sigma_{a c s}$, which must be reduced;

- modulus of elasticity of triboelement materials $E_{m o v}, E_{f i x}$, which must be increased;

- tribological properties of the lubricating medium $E_{u}$, which need to be increased.

2. Increasing the rate of deformation in the surface layers of triboelements. Ways to increase $\dot{\varepsilon}_{m o v}$ and $\dot{\varepsilon}_{f i x}$ follow from expressions (9) and (10).

Analysis of these expressions allows us to conclude that the values $\sigma_{a c s}, E_{m o v}, E_{f i x}$ are in contradiction with the conclusions made earlier. So the magnitude $T_{3}$ will be optimal for the process of self-organization. One of the parameters that can control the value $T_{3}$, this is the sliding speed $v_{s l}$. Increasing the sliding speed leads to an increase in the strain rate under pre-selected and constant conditions.

The expressions for determining the gain are obtained $K_{1}-K_{3}$, formulas (4) - (7), as well as time constants $T_{1}-T_{3}$, formulas (11) - (14), is the result of parametric identification of the mathematical model of functioning of tribosystems in the conditions of extreme lubrication.

\section{Conclusions}

Parametric identification of the tribosystem as an object of modeling the functioning of tribosystems in the conditions of boundary lubrication is performed. Using the analysis of the dimensions of significant factors, expressions are obtained to calculate the gain and time constants.

It is established that the coefficient $K_{1}$ takes into account the degree of influence of the load, sliding speed, tribological characteristics of the lubricating medium on the quality factor of the tribosystem. It is shown that the increase in the coefficient $K_{1}$ will have a positive effect on the processes inherent in tribosystems during operation. Coefficient $K_{2}$ - characterizes the magnitude of the change in volumetric wear rate and coefficient of friction when changing the magnitude of the load, sliding speed, quality factor of the tribosystem. Coefficient $K_{3}$ - characterizes the ability of the tribosystem to self-organize when changing the values of the input parameters by rearranging the surface layers of materials from which the triboelements are made during secondary running-in. Outrageous forces include load, sliding speed, tribological characteristics of the lubricating medium, quality factor of the tribosystem. It is shown that the value of the coefficient $K_{3}$ is large, will contribute to the rapid change in the roughness of the friction surfaces, the restructuring of the structure of the surface layers, the appearance of oxidizing films on the friction surfaces (secondary structures). 
It is proved that the time constant $T_{1}$ - this is the time required to change the roughness of the friction surfaces and rearrange the structure of the materials of the surface layers when changing external conditions. Time constant $T_{2}$ characterizes the time during which there is a stabilization of the temperature gradient by volume of triboelements, taking into account the thermal conductivity of materials when changing external conditions. Time constant $T_{3}$ characterizes the time for which the tribosystem returns to a steady state of operation after the cessation of the outrageous force, or the time to stabilize the parameters in the new mode of operation. It is proved that the value $T_{3}$ will be optimal for the process of self-organization. One of the parameters that can control the value $T_{3}$, this is the sliding speed $v_{s l}$. Increasing the sliding speed leads to an increase in the strain rate under pre-selected and constant conditions.

The expressions for determining the coefficients are obtained $K_{1}-K_{3}$, as well as time constants $T_{1}-T_{3}$, is the result of parametric identification of the mathematical model of functioning of tribosystems in the conditions of extreme lubrication. The value of these coefficients will be used in modeling the processes of friction and wear in tribosystems when changing design, technological and operational parameters, which will allow to choose rational designs for specific conditions of their operation.

\section{References}

1. Voitov, A. (2021). Structural identification of the mathematical model of the functioning of tribosystems under conditions of boundary lubrication. Problems of Tribology, 26(2/100), 2633. https://doi.org/10.31891/2079-1372-2021-100-2-26-33 [English]

2. Markus Schewe, Hendrik Wilbuer, Andreas Menzel Simulation of wear and effective friction properties of microstructured surfaces // Wear, Volumes 464-465, 2021, 203491. https://doi.org/10.1016/j.wear.2020.203491 [English]

3. Han $\mathrm{Hu}$, Anas Batou, Huajiang Ouyang Coefficient of friction random field modelling and analysis in planar sliding // Journal of Sound and Vibration, Volume 508, 2021, 116197. https://doi.org/10.1016/i.jsv.2021.116197 [English]

4. D. Lucente, A. Petri, A. Vulpiani A Markovian approach to the Prandtl-Tomlinson frictional model // Physica A: Statistical Mechanics and its Applications, Volume 572, 2021, 125899. https://doi.org/10.1016/j.physa.2021.125899 [English]

5. Zaspa, Y., Dykha, A., Marchenko, D., et al. Exchange interaction and models of contact generation of disturbances in tribosystems. Eastern-European Journal of Enterprise Technologies, 2020, 4(5-106), p. $25-34$. https://doi.org/10.15587/1729-4061.2020.209927 [English]

6. Sorokatyi, R., Chernets, M., Dykha, A., et al. (2019). Phenomenological Model of Accumulation of Fatigue Tribological Damage in the Surface Layer of Materials. In Mechanisms and Machine Science, $2019, \mathrm{~V}$. 73, p. 3761-3769. Springer Netherlands. https://doi.org/10.1007/978-3-030-20131-9 371 [English]

7. Dykha, A., Aulin, V., Makovkin, O., et al. Determining the characteristics of viscous friction in the sliding supports using the method of pendulum. Eastern-European Journal of Enterprise Technologies, 2017, 3(7-87), 4-10. https://doi.org/10.15587/1729-4061.2017.99823 [English] [Russian]

8. Sorokatyy R.V. Metod triboelementov / R.V. Sorokatyy. - Khmel'nitskiy: KHNU, 2009. - 242 s.

9. Vojtov V.A., Zakharchenko M.B. Modelirovaniye protsessov treniya iznashivaniya v tribosistemakh v usloviyakh granichnoy smazki. Chast' 1. Raschet skorosti raboty dissipatsii v tribosistemakh / Problemi tribologiï. - 2015. - № 1. - S. 49-57. [Russian]

10. Vojtov V.A. Printsipy konstruktivnoy iznosostoykosti uzlov treniya gidromashin / V.A. Vojtov, O.M. Yakhno, F.KH. Abi-Saab. - K.: KPI, 1999. - 192 s. [Russian]

11. Vojtov V.A., Zakharchenko M.B. Yntehral'nyy parametr otsenky trybolohycheskykh svoystv smazochnykh materyalov // Zbirnyk naukovykh prats' Ukrayins'koyi derzhavnoyi akademiyi zaliznychnoho transportu. Tom 2. - Kharkiv: UkrDAZT, 2015. - Vyp. 151. - S. 5 - 10. [Russian]

12. Voitov A. V. Zalezhnosti zminy reolohichnykh vlastyvostey struktury spoluchenykh materialiv u trybosystemi pid chas prypratsyuvannya // Problemy tertya ta znoshuvannya. 2020. - №. 3 (88). - S. 71-78. http://dx.doi.org/10.18372/0370-2197.3(88).14921 [Ukrainian]

13. Vojtov V.A., Voitov A.V. Assessment of the quality factor of tribosystems and it's relationship with tribological characteristics // Problems of Tribology, V. 25, No 4/97 - 2020, 45-49. DOI: 10.31891/2079-13722020-97-3-45-49 [English] 
Войтов А.В. Параметрична ідентифікація математичної моделі функціонування трибосистем в умовах граничного мащення.

Виконано параметричну ідентифікацію трибосистеми, як об'єкта моделювання функціонування трибосистем в умовах граничного мащення. За допомогою аналізу розмірностей значимих факторів отримано вирази для розрахунку коефіцієнтів підсилення та постійних часу.

Встановлено, що коефіцієнт $K_{1}$ враховує ступінь впливу навантаження, швидкості ковзання, трибологічних характеристик змащувального середовища на величину добротність трибосистеми. Показано, що збільшення коефіцієнта $K_{1}$ буде позитивно впливати на процеси, які притаманні трибосистемам під час експлуатації. Коефіцієнт $K_{2}$ - характеризує величину зміни об'ємної швидкості зношування і коефіцієнта тертя при зміні величин навантаження, швидкості ковзання, добротності трибосистеми. Коефіцієнт $K_{3}$ - характеризує здатність трибосистеми до самоорганізації при зміні величин вхідних параметрів шляхом перебудови поверхневих шарів матеріалів 3 яких виготовлені трибоелементи під час вторинного припрацювання. До сил, що обурюють, відносяться навантаження, швидкість ковзання, трибологічні характеристики змащувального середовища, добротність трибосистеми. Показано, що велике значення коефіцієнта $K_{3}$ буде сприяти швидкої зміні величин шорсткості поверхонь тертя, перебудові структури поверхневих шарів, появі окиснювальних плівок на поверхнях тертя (вторинних структур).

Доведено, що постійної часу $T_{1}$ - це час, який необхідно для зміни шорсткості поверхонь тертя та перебудови структури матеріалів поверхневих шарів при зміні зовнішніх умов. Постійна часу $T_{2}$ характеризує час, за який відбувається стабілізації градієнта температур за об'ємами трибоелементів 3 урахуванням температуропровідності матеріалів при зміні зовнішніх умов. Постійна часу $T_{3}$ характеризує час, за який відбувається повернення трибосистеми до сталого режиму функціонування після припинення дії сили, що обурює, або час до стабілізації параметрів на новому режимі функціонування. Доведено, що величина $T_{3}$ матиме оптимальне значення для процесу самоорганізіції. Доведено, що одним 3 факторів, яким можна керувати величиною $T_{3}$, це швидкість ковзання $v_{\text {ков. }}$ Збільшення швидкості ковзання призводить до збільшення швидкості деформації при заздалегідь обраних і незмінних умовах.

Отримані вирази для визначення коефіцієнтів $K_{1}-K_{3}$, а також постійних часу $T_{1}-T_{3}, \epsilon$ результатом параметричної ідентифікації математичної моделі функціонування трибосистем в умовах граничного мащення. Значення цих коефіцієнтів буде використано при моделюванні процесів тертя та зношування в трибосистеми при зміні конструктивних, технологічних та експлуатаційних параметрів, що дозволить обирати раціональні конструкції для конкретних умов їх експлуатації.

Ключові слова: трибосистема; математична модель; диференційні рівняння; параметрична ідентифікація; коефіцієнт посилення; постійна часу; граничне змащення; добротність трибосистеми; швидкість роботи дисипації 